\begin{tabular}{|l|l|}
\hline $\begin{array}{l}\text { 2. To: (Receiving organization) } \\
\text { Distribution }\end{array}$ & $\begin{array}{l}\text { 3. From: (Originating Organization) } \\
\text { J. G. Field, LMHC, R2-12 }\end{array}$ \\
\hline 5. Proj./Prog./Dept./Div.: & $\begin{array}{l}\text { 6. Design Authority/ Design Agent/Cog } \\
\text { Engr.: M. J. Kupfer }\end{array}$ \\
Tank 241-T-202 & \multicolumn{1}{|l}{ M. Kunfer }
\end{tabular}

4. Related EDT No.:

8. Originator Remarks:

Approva1/Release

11. Receiver Remarks: 11A. Design Basel ine Document? [] Yes [X] No

NA

7. Purchase Order No.:

NA

9. Equip./Component No.:

NA

10. Systen/Bldg./Facility: NA

12. Major Assm. Dug. No.:

NA

13. Permit/Permit Application No.:

NA

14. Required Response Date:

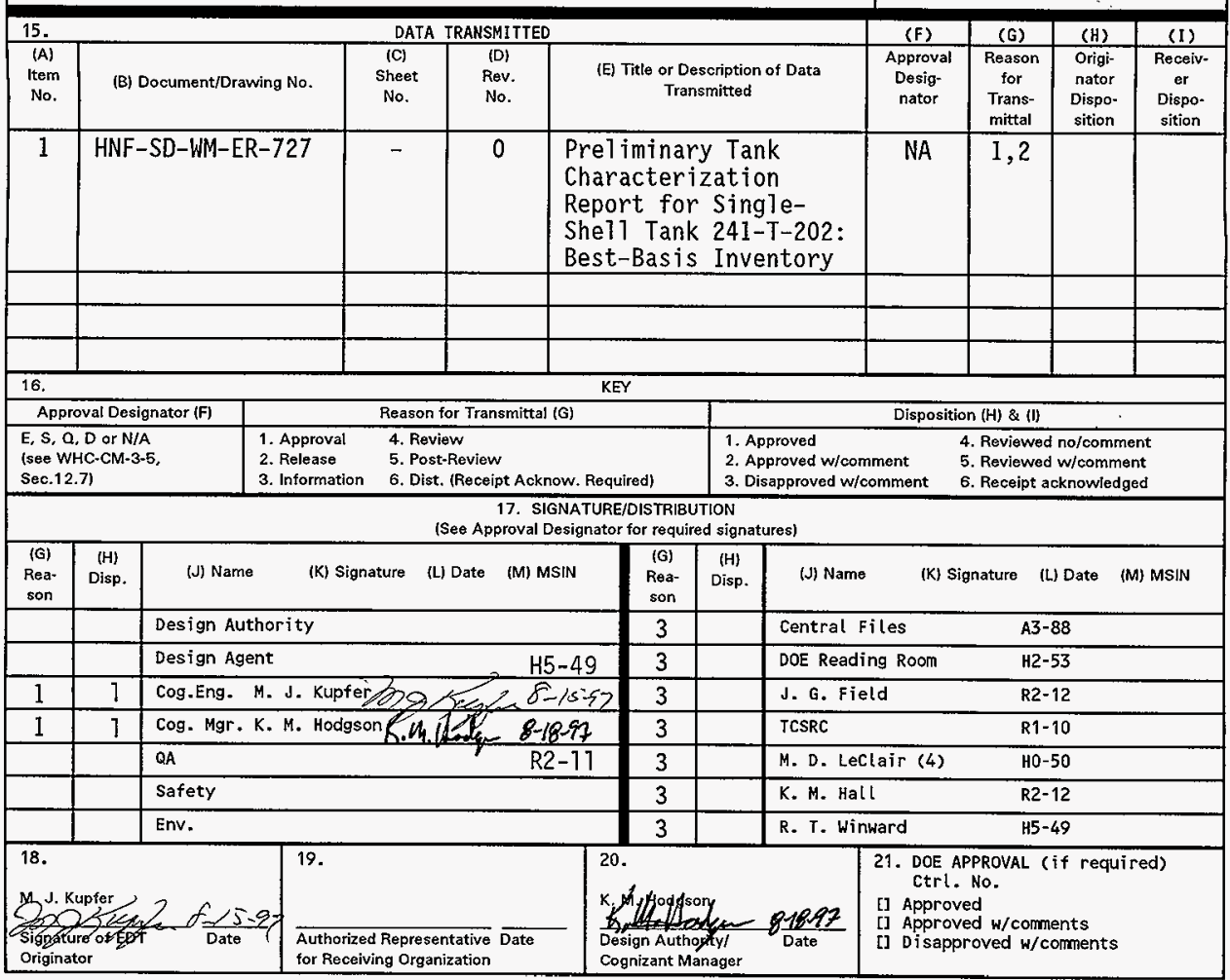

BD-7400-172-2 (05/96) GEF097 


\title{
Preliminary Tank Characterization Report for Single-Shell Tank 241-T-202: Best-Basis Inventory
}

\author{
J. G. Field \\ Lockheed Martin Hanford Corporation, Richland, WA 99352 \\ U.S. Department of Energy Contract DE-AC06-96RL13200
}

EDT/ECN: 161472

Org Code: 74610

B\&R Code: EW3120074
UC: 712

Charge Code: N4G3A

Total Pages: 23

Key Words: TCR, best-basis inventory

Abstract: An effort is underway to provide waste inventory estimates that will serve as standard characterization source terms for the various waste management activities. As part of this effort, an evaluation of available information for single-shell tank 241-T-202 was performed, and a best-basis inventory was established. This work follows the methodology that was established by the standard inventory task.

TRADEMARK DISCLAIMER. Reference herein to any specific comercial product, process, or service by trade name, trademark, manufacturer, or otherwise, does not necessarily constitute or imply its endorsement, recommendation, or favoring by the United States Government or any agency thereof or its contractors or subcontractors.

Printed in the United States of America. To obtain copies of this document, contact: Document Control Services, P.0. Box 950, Mailstop H6-08, Richland WA 99352, Phone (509) 372-2420; Fax (509) 376-4989.

$\frac{\text { Aande }}{\text { Belease Approval }} \frac{8-21-97}{\text { Date }}$

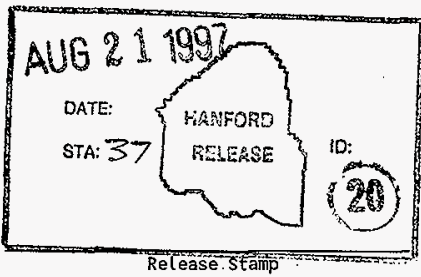




\title{
PRELIMINARY TANK CHARACTERIZATION REPORT FOR SINGLE-SHELL TANK 241-T-202: BEST-BASIS INVENTORY
}

August 1997

\author{
J. G. Field \\ Lockheed Martin Hanford Corporation \\ Richland, Washington
}

\author{
R. T. Winward \\ Meier and Associates \\ Richland, Washington
}

Prepared for

U.S. Department of Energy

Richland, Washington 
HNF-SD-WM-ER-727

Revision 0

This page intentionally left blank. 


\section{PRELIMINARY TANK CHARACTERIZATION REPORT FOR SINGLE-SHELL TANK 241-T-202: \\ BEST-BASIS INVENTORY}

This document is a preliminary Tank Characterization Report (TCR). It only contains the current best-basis inventory (Appendix D) for single-shell tank 241-T-202. No TCRs have been previously issued for this tank, and current core sample analyses are not available. The best-basis inventory, therefore, is based on an engineering assessment of waste type, process flowsheet data, early sample data, and/or other available information.

The Standard Inventories of Chemicals and Radionuclides in Hanford Site Tank Wastes (Kupfer et al. 1997) describes standard methodology used to derive the tank-by-tank best-basis inventories. This preliminary TCR will be updated using this same methodology when additional data on tank contents become available.

\section{REFERENCE}

Kupfer, M. J., A. L. Boldt, B. A. Higley, K. M. Hodgson, L. W. Shelton, and R. A. Watrous (LMHC), S. L. Lambert, and D. E. Place (SESC), R. M. Orme (NHC), G. L. Borsheim (Borsheim Associates), N. G. Colton (PNNL), M. D. LeClair (SAIC), R. T. Winward (Meier Associates), and W. W. Schulz (W2S Corporation), 1997, Standard Inventories of Chemicals and Radionuclides in Hanford Site Tank Wastes, HNF-SD-WM-TI-740, Rev. 0, Lockheed Martin Hanford Corporation, Richland, Washington. 
HNF-SD-WM-ER-727

Revision 0

This page intentionally left blank. 
HNF-SD-WM-ER-727

Revision 0

APPENDIX D

\section{EVALUATION TO ESTABLISH BEST-BASIS INVENTORY FOR SINGLE-SHELL TANK 241-T-202}




\section{HNF-SD-WM-ER-727}

\section{Revision 0}

This page intentionally left blank. 
APPENDIX D

\section{EVALUATION TO ESTABLISH BEST-BASIS INVENTORY FOR SINGLE-SHELL TANK 241-T-202}

An effort is underway to provide waste inventory estimates that will serve as standard characterization source terms for the various waste management activities (Hodgson and LeClair 1996). As part of this effort, an evaluation of available information for single-shell tank 241-T-202 was performed, and a best-basis inventory was established. This work, detailed in the following sections, follows the methodology that was established by the standard inventory task.

\section{D1.0 CHEMICAL INFORMATION SOURCES}

There is no tank characterization report for this tank. The information provided in Pool (1994) provides characterization results for tank 241-B-202 which contains the same type of waste as 241-T-202.

\section{D2.0 COMPARISON OF COMPONENT INVENTORY VALUES}

Pool (1994) provides characterization results from the most recent sampling event for tank 241-B-202. Two core samples were obtained and analyzed. Due to incomplete recovery of the waste during sampling, the characterization results for tank 241-B-202 could be biased, but this sample information provides the best current information for tanks 241-B-202 and 241-T-202.

Sample-based inventories listed in Tables D2-1 and D2-2 were calculated by multiplying the mean concentration and density of waste in tank $241-\mathrm{B}-202(1.21 \mathrm{~kg} / \mathrm{L})$ by the volume of waste in tank 241-T-202. (The chemical species are reported without charge designation per the best-basis inventory convention). Tank 241-T-202 is reported to contain $80 \mathrm{~kL}$ (21 kgal) of waste (Hanlon 1997). The HDW-based inventory was derived using this same waste volume and density. 


\section{Revision 0}

Table D2-1. Engineering and Hanford Defined Waste-based Inventory Estimates for Tank 241-T-202 Nonradioactive Components.

\begin{tabular}{|c|c|c||c|c|c|}
\hline Analyte & $\begin{array}{c}\text { Engineering } \\
\text { inv. estimate } \\
(\mathrm{kg})\end{array}$ & $\begin{array}{c}\text { HDW inv. } \\
\text { estimate } \\
(\mathrm{kg})\end{array}$ & Analyte & $\begin{array}{c}\text { Engineering } \\
\text { inv. estimate } \\
(\mathrm{kg})\end{array}$ & $\begin{array}{c}\text { HDW inv. } \\
\text { estimate } \\
(\mathrm{kg})\end{array}$ \\
\hline $\mathrm{Al}$ & 93.0 & 0.00 & $\mathrm{Na}$ & 3,530 & 7,740 \\
\hline $\mathrm{Bi}$ & 3,111 & 923 & $\mathrm{Ni}$ & 19.1 & 6.64 \\
\hline $\mathrm{Ca}$ & 149 & 779 & $\mathrm{NO}_{2}$ & 52.0 & 11.7 \\
\hline $\mathrm{Ce}$ & 10.0 & $\mathrm{NR}$ & $\mathrm{NO}_{3}$ & 6,020 & 6,040 \\
\hline $\mathrm{Cl}$ & 79.0 & 66.8 & $\mathrm{~Pb}$ & 60.0 & $\mathrm{NR}$ \\
\hline $\mathrm{Cr}$ & 230 & 25.0 & ${\mathrm{P} \mathrm{as} \mathrm{PO}_{4}}^{\mathrm{b}}$ & 856 & 634 \\
\hline $\mathrm{Cu}$ & 25.0 & $\mathrm{NR}$ & $\mathrm{Si}$ & 311 & 0 \\
\hline $\mathrm{F}$ & 593 & 1,530 & $\mathrm{SO}_{4}$ & 134 & 20.4 \\
\hline $\mathrm{Fe}$ & 622 & 1,610 & $\mathrm{Sr}$ & 55.0 & 0 \\
\hline $\mathrm{K}$ & 631 & 638 & $\mathrm{TIC} \mathrm{as} \mathrm{CO_{3 }}$ & 172 & 1,170 \\
\hline $\mathrm{La}$ & 1,250 & 37.3 & $\mathrm{Zn}$ & 52.0 & $\mathrm{NR}$ \\
\hline $\mathrm{Mg}$ & 23.0 & $\mathrm{NR}$ & $\mathrm{H}_{2} \mathrm{O}(\mathrm{wt} \%)$ & 75.8 & 68.6 \\
\hline $\mathrm{Mn}$ & 1,250 & 19.8 & density $(\mathrm{g} / \mathrm{mL})$ & 1.21 & 1.21 \\
\hline $\mathrm{HDW}$ & & & & \\
\hline
\end{tabular}

HDW $=$ Hanford Defined Waste

$\mathrm{NR}=$ Not reported kgal)

${ }^{2}$ Pool (1994) multiplied by a density of $1.21 \mathrm{~kg} / \mathrm{L}$ and tank volume of $80 \mathrm{~kL}(21$

${ }^{b}$ Agnew et al. (1997a).

Table D2-2. Engineering and Hanford Defined Waste-based Inventory Estimates for

Radioactive Components in Tank 241-T-202

\begin{tabular}{|c|c|c||c|c|c|}
\hline Analyte & $\begin{array}{c}\text { Sampling } \\
\text { inv. estimate } \\
(\mathrm{Ci})\end{array}$ & $\begin{array}{c}\text { HDW } \\
\text { inv. estimate } \\
(\mathrm{Ci})\end{array}$ & Analyte & $\begin{array}{c}\text { Sampling } \\
\text { inv. estimate } \\
(\mathrm{Ci})\end{array}$ & $\begin{array}{c}\mathrm{HDW}^{\mathrm{b}} \\
\text { inv. estimate } \\
\text { (Ci) }\end{array}$ \\
\hline${ }^{90} \mathrm{Sr}$ & 349 & 13.7 & ${ }^{239240} \mathrm{Pu}$ & 19 & 0.0379 \\
\hline${ }^{137} \mathrm{Cs}$ & 2.4 & 15.5 & ${ }^{241} \mathrm{Am}$ & 6.14 & $2.85 \mathrm{E}-04$ \\
\hline
\end{tabular}

HDW $=$ Hanford Defined Waste

NR $=$ Not reported

a Pool (1994), decayed to January 1, 1994

${ }^{b}$ Agnew et al. (1997a), decayed to January 1, 1994. 
HNF-SD-WM-ER-727

Revision 0

\section{D3.0 COMPONENT INVENTORY EVALUATION}

The following evaluation provides a best-basis inventory estimate for chemical and radionuclide components in tank $241-\mathrm{T}-202$.

\section{D3.1 CONTRIBUTING WASTE TYPES}

The following abbreviations were used to designate waste types:

$224=\mathrm{LaF}_{3}$ final plutonium decontamination and concentration waste from the $\mathrm{BiPO}_{4}$ process

$1 \mathrm{C}=$ First decontamination cycle $\mathrm{BiPO}_{4}$ waste, operational 1944 to 1956.

Agnew et al. (1997b) first shows waste in the 200 series tanks in 1952 for B and T Tank Farms, and in 1956 for U Tank Farm. However, Borsheim (1994) reports that originally the 224 wastes were routed to the $6.1 \mathrm{~m} \mathrm{(20} \mathrm{ft)}$ diameter concrete settling tank (241-361) and overflowed from there to a dry well. The dry well was replaced with a crib by June 1945 .

Cell drainage (5 to 6 waste) was also routed to the 241-361 tank. High activity cell drainage was supposed to be routed to tanks $241-\mathrm{B}-107$ and $241-\mathrm{T}-107$ in the $1 \mathrm{C}$ waste cascades. Borsheim (1994) also notes that the 200 series tanks were each provided with two inlet lines, were not cascaded, and had no overflow lines. Experiments (as of

November 1944) indicated that the 224 wastes should contain 3 percent solids by volume.

Borsheim (1994) notes that the "Hanford Works Monthly Reports" show a plan to provide a separate crib for the B Plant cell drainage. The cell drainage was then being disposed to tank $241-\mathrm{B}-201$ along with the 224 waste. Tank $241-\mathrm{B}-201$ and the $\mathrm{T}$ tanks were in service as sludge settling tanks for 224-B and $\mathrm{T}$ wastes, respectively. The remaining 200 series tanks $(202,203,204)$ were being excavated and piped in series to increase settling capacity.

Borsheim (1994) reports that by July 1950, tank 241-B-204, which had been in service since November 1948, was filled to a depth of $6.1 \mathrm{~m}(20 \mathrm{ft})$ with sludge. The tank overflowed to tank 241-B-203 which had received $10.2 \mathrm{~cm}$ (4 in.) of sludge by that time. This suggests that tanks 241-B-201 and 241-T-201 received 224 waste before the other B-200 and T-200 series tanks, and that when the other B-200 series tanks received waste, it overflowed from tank $241-\mathrm{B}-204$ to tank 241-B-203 and to tank 241-B-202. The T-200 series tanks received 224 waste in a similar fashion.

The waste volumes in tanks 241-B-204, 241-B-203, and 241-B-202 are $189 \mathrm{~kL}$ (50 kgal), $193 \mathrm{~kL}(51 \mathrm{kgal})$, and $102 \mathrm{~kL}(27 \mathrm{kgal})$, respectively (Hanlon 1997). Tank. 241-B-201 contains $110 \mathrm{~kL}$ (29 kgal) and is piped separately from the other B-200 tanks, 


\section{Revision 0}

indicating that it received waste independent of the other three B-200 series tanks. The T-200 series tank waste volumes show the same trends.

\section{Expected Types of Solids in the Waste}

Hill et al. (1995): 224

Agnew et al (1997a): 224

\section{D3.2 EVALUATION OF FLOWSHEET INFORMATION}

Technical flowsheet information (Kupfer et al. 1997) for' 224 streams is shown in Table D3-1. The comparative HDW model defined waste streams are also shown in Table D3-1.

Table D3-1. Technical Flowsheet and Hanford Defined Waste Defined Waste Streams.

\begin{tabular}{|c|c|c|c|}
\hline Analyte & $\begin{array}{c}\text { Flowsheet 224 } \\
\text { (Place) }\end{array}$ & $\begin{array}{c}\text { Flowsheet } 224^{\mathrm{a}}(M) \\
\text { (Schneider) }\end{array}$ & HDW 224 $(M)$ \\
\hline $\mathrm{Bi}$ & 0.00595 & 0.00565 & 0.006 \\
\hline $\mathrm{C}_{2} \mathrm{O}_{4}$ & 0.0458 & 0.0147 & 0.046 \\
\hline $\mathrm{Cr}$ & 0.00362 & 0.00327 & 0.0068 \\
\hline $\mathrm{F}$ & 0.272 & 0.295 & 0.27 \\
\hline $\mathrm{K}$ & 0.223 & 0.218 & 0.231 \\
\hline $\mathrm{La}$ & 0.00376 & 0.00353 & 0.0038 \\
\hline $\mathrm{Mn}$ & 0.00514 & 0.00601 & 0.0051 \\
\hline $\mathrm{Na}$ & 1.62 & 1.60 & 1.60 \\
\hline $\mathrm{NO}_{3}$ & 1.06 & 0.684 & 1.38 \\
\hline $\mathrm{PO}_{4}$ & 0.0322 & 0.0321 & 0.038 \\
\hline $\mathrm{SO}_{4}$ & 0.00140 & 0.00364 & 0.003 \\
\hline $\mathrm{NH}_{4}$ & $\mathrm{NR}$ & 0.0067 & $\mathrm{NR}$ \\
\hline
\end{tabular}

HDW $=$ Hanford Defined Waste

$\mathrm{NR}=$ Not Reported

appendix C of Kupfer et al. (1997), Bismuth Phosphate Process Flowsheet

b Agnew et al. (1997a). 
HNF-SD-WM-ER-727

Revision 0

\section{D3.3 ASSUMPTIONS FOR RECONCILING WASTE INVENTORIES}

Reference inventories in tank 241-T-202 were estimated using an engineering assessment that is based on the results of a sampling event from tank 241-B-202, that has a nearly identical history and contains the same waste type. The inventories were then compared with the HDW model inventories. The assumptions and observations for the engineering assessment were based on best technical judgement pertaining to input information that can significantly influence tank inventories. This includes: (1) correct prediction of contributing waste types, and correct relative proportions of the waste types, (2) accurate predictions of flowsheet conditions, fuel processed, and waste volumes, (3) accurate predictions of partitioning of components, and (4) accurate predictions of physical parameters such as density, percent solids, etc. By using this evaluation, the assumptions can be modified as necessary to provide a basis for identifying potential errors and/or missing information that could influence the sample- and model-based inventories. The following are simplified assumptions and observations used for the evaluation.

- Tank waste mass is calculated using the measured density and the tank volume listed in Hanlon (1997). Both engineering assessment-based and model-based inventories are derived using this volume. As a result, inventory comparisons are made on the same volume basis.

- Only the 224 waste stream contributed to solids formation. It is assumed that tanks with the same waste type will have the same concentrations of individual analytes.

- Bulk component (chemical species) information is sufficient for comparing the computed data sets. This information can be obtained from technical flowsheets (see Table D3-1).

\section{D3.4 BASIS FOR CALCULATIONS USED IN THIS ENGINEERING EVALUATION}

Because analytical data from a sampling event does not exist for tank 241-T-202, a comparison of sample data to flowsheet derived data cannot be done. A review of waste transfer transaction records (Agnew et al.1997b) confirms that the waste in this tank is from the 224 process. Hill et al. (1995) and Anderson (1990) agree with the designation of the waste in tank 241-T-202 as 224 waste.

The best-basis evaluation for tank 241-B-202 (Field et al. 1997) includes a comparison of the sample data to flowsheet predictions for 224 waste and shows good agreement between the sample data and the flowsheet predictions. Since tanks 241-B-202 and 241-T-202 received the same waste, in the same time period, and are located in the same position in their respective cascades it is appropriate to use the tank 241-B-202 sample results to estimate the inventories for tank 241-T-202. 


\section{Revision 0}

The inventories for tank 241-T-202 were estimated using the measured concentration of analytes for tank 241-B-202 and multiplying the concentration by a density of $1.21 \mathrm{~kg} / \mathrm{L}$ and volume of $80 \mathrm{~kL}$ ( $21 \mathrm{kgal})$. Estimated component inventories from this engineering evaluation are compared with the HDW-estimated based inventories in Table D3-2. Observations regarding these inventories are noted by component in the following text.

Table D3-2. Comparison of Selected Component Inventory Estimates for Tank 241-T-202.

\begin{tabular}{|c|c|c|}
\hline Component & This evaluation $(\mathrm{kg})$ & HDW estimated \\
\hline $\mathrm{Bi}$ & $\mathrm{kg})$ \\
\hline $\mathrm{K}$ & 3,111 & 923 \\
\hline $\mathrm{La}$ & 631 & 638 \\
\hline $\mathrm{NO}_{3}$ & 1,250 & 37.3 \\
\hline $\mathrm{Mn}$ & 6,020 & 6,040 \\
\hline $\mathrm{SO}_{4}$ & 1,250 & 19.8 \\
\hline $\mathrm{Cr}$ & 134 & 20.4 \\
\hline $\mathrm{PO}_{4}$ & 230 & 25.0 \\
\hline $\mathrm{F}$ & 856 & 634 \\
\hline $\mathrm{Na}$ & 593 & 1,530 \\
\hline $\mathrm{H}_{2} \mathrm{O} \%$ & 3,530 & 7,740 \\
\hline
\end{tabular}

HDW $=$ Hanford Defined Waste

agnew et al. (1997a).

Bismuth. The HDW model estimate is about three times lower than the engineering estimate. This appears to be caused by the assumption in the HDW that bismuth is partially soluble.

Nitrate. The HDW estimate is about the same as the engineering assessment results. The HDW estimated inventory is derived from the HDW model defined 224 waste stream, in which the nitrate concentration is about 30 percent higher than the Place flowsheet (Appendix C of Kupfer et al. 1997).

Sulfate. The HDW estimated inventory is smaller than the engineering assessment-based inventory. Schneider's waste stream estimate is about three times higher 
for sulfate than is Place's (Kupfer et al. 1997). If the Schneider value is used in the HDW model, the HDW would probably more closely agree with the assessment value.

Chromium. The HDW estimated inventory is considerably lower than the sample-based inventory. The data for tank 241-B-202 (Pool 1994) suggests that about 30 percent of the chromium precipitated while the HDW model assumes a much smaller percent.

Phosphate. The engineering assessment phosphate value is close to the HDW value.

Fluoride. The engineering assessment is based on water soluble fluoride only. The assessment value is about three times. lower than the HDW value. Until a sample is analyzed by a methodology that measures total fluoride, these differences cannot be reconciled.

Sodium. The HDW value is approximately two times higher than the value from the engineering estimate.

Potassium. The HDW and sampling values for potassium agree fairly well.

Lanthanum. Based on the tank 241-B-202 (Pool 1994) data, lanthanum appears to partition between the phases in the tank. The HDW model value is much lower than the engineering estimate for this analyte.

Manganese. The value from the engineering evaluation is much larger than that predicted by Agnew et al. (1997a). The HDW model treats manganese as a highly soluble in the B and T-200 series tanks and predicts much less manganese in the waste..

Total Hydroxide. Once the best basis inventories were determined, the hydroxide inventory can be calculated by performing a charge balance with the valences of other analytes. In some cases this approach requires that other analyte (e.g., sodium or nitrate) inventories be adjusted to achieve the charge balance. During such adjustments the number of significant figures is not increased. This charge balance approach was consistent with that used by Agnew et al. (1997a). The total hydroxide inventories calculated from a charge balance based on engineering assessments and HDW model estimates were $3,460 \mathrm{~kg}$ and $1,490 \mathrm{~kg}$, respectively. The $\mathrm{OH}$ inventory based on tank 241-B-202 sample measurements was $593 \mathrm{~kg}$. The sample based inventory for tank 241-B-202 was selected as the best basis for tank 241-T-202.

\section{Comments On Other Analytes}

Strontium. The HDW model assumes there is no strontium in the 224 waste. However, the engineering assessment indicates that tank 241-T-202 may contain $55 \mathrm{~kg}$ of strontium. 


\section{HNF-SD-WM-ER-727}

\section{Revision 0}

Plutonium. Although the amount of plutonium was low, it was much higher than predicted by the HDW model. The process flowsheet did not contain plutonium values, so plutonium could not be evaluated in the engineering analysis. 
HNF-SD-WM-ER-727

Revision 0

\section{D4.0 DEFINE THE BEST-BASIS AND ESTABLISH COMPONENT INVENTORIES}

Information about chemical, radiological, and/or physical properties is used to perform safety analyses, engineering evaluations, and risk assessment associated with waste management activities and to address regulatory issues. These activities include overseeing tank farm operations and identifying, monitoring, and resolving safety issues associated with these operations and with the tank wastes. Disposal activities include designing equipment, processes, and facilities for retrieving wastes, and processing them into a form suitable for long-term storage/disposal.

Chemical and radiological inventory information are generally derived using three approaches: (1) component inventories are estimated using the results of sample analyses, (2) component inventories are predicted using the HDW model based on process knowledge and historical information, or (3) a tank-specific process estimate is made based on process flowsheets, reactor fuel data, essential material usage, and other operating data. The information derived from these different approaches is often inconsistent.

As part of this effort, an evaluation of available chemical information for tank 241-T-202 was performed, including the following:

- Data from two core samples of tank 241-B-202 (Pool 1994).

- An inventory estimate generated by the HDW model (Agnew et al. 1997a).

The calculations based on flowsheet information and factors determined from the bismuth analytical data from tank 241-B-202 have been compared to analytical data (Field et al. 1994) and the HDW model (Agnew et al. 1997a). These calculations compare well with the analytical data and, in some cases, with the HDW model. Given current resources, the best source of inventory data appears to be the analytical data which was obtained during the core sampling and analysis event from tank 241-B-202. One analyte, for which the analytical data is suspect is fluoride. Only the water soluble forms of fluoride are reported in the analytical data. Tables D4-1 and D4-2 present the best-basis inventory estimates for the nonradioactive and radioactive waste components, respectively. The inventory values reported in Tables D4-1 and D4-2 are subject to change. Refer to the Tank Characterization Database (TCD) for the most current inventory values.

Best-basis tank inventory values are derived for 46 key radionuclides (as defined in Section 3.1 of Kupfer et al. 1997), all decayed to a common report date of January 1, 1994. Often, waste sample analyses have only reported ${ }^{90} \mathrm{Sr},{ }^{137} \mathrm{Cs},{ }^{239 / 240} \mathrm{Pu}$, and total uranium (or total beta and total alpha), while other key radionuclides such as ${ }^{60} \mathrm{Co},{ }^{99} \mathrm{Tc},{ }^{129} \mathrm{I},{ }^{154} \mathrm{Eu},{ }^{155} \mathrm{Eu}$, and ${ }^{241} \mathrm{Am}$, etc., have been infrequently reported. For this reason it has been necessary to derive most of the $46 \mathrm{key}$ radionuclides by computer models. These models estimate radionuclide activity in batches of reactor fuel, account for the split of radionuclides to various separations plant waste streams, and track their movement with tank waste transactions. (These computer models are described in Kupfer et al. 1997, Section 6.1 and 


\section{Revision 0}

in Watrous and Wootan 1997.) Model generated values for radionuclides in any of 177 tanks are reported in the HDW Rev. 4 model results (Agnew et al. 1997a). The best-basis value for any one analyte may be either a model result or a sample or engineering assessment-based result if available. (No attempt has been made to ratio or normalize model results for all 46 radionuclides when values for measured radionuclides disagree with the model.) For a discussion of typical error between model derived values and sample derived values, see Kupfer et al. 1997, Section 6.1.10. The radionuclide inventories shown in Table D4-2 are based primarily on Agnew et al. (1997a) HDW model estimates for tank 241-T-202.

Table D4-1. Best-Basis Inventory Estimate for Nonradioactive Components in Tank 241-T-202 (Effective May 31, 1997). (2 Sheets)

\begin{tabular}{|c|c|c|c|}
\hline Analyte & $\begin{array}{c}\text { Total inventory } \\
(\mathrm{kg})\end{array}$ & $\begin{array}{c}\text { Basis } \\
(\mathrm{S}, \mathrm{M}, \mathrm{E}, \text { or } \mathrm{C})^{1} \\
\end{array}$ & Comment \\
\hline $\mathrm{Al}$ & 93 & $\mathrm{E}$ & \\
\hline $\mathrm{Bi}$ & 3,111 & $\mathrm{E}$ & \\
\hline $\mathrm{Ca}$ & 149 & $\mathrm{E}$ & \\
\hline $\mathrm{Cl}$ & 79 & $\mathrm{E}$ & \\
\hline $\mathrm{TIC}$ as $\mathrm{CO}_{3}$ & 172 & $\mathrm{E}$ & \\
\hline $\mathrm{Cr}$ & 230 & $\mathrm{E}$ & \\
\hline$F$ & 593 & $\mathrm{E}$ & \\
\hline $\mathrm{Fe}$ & 622 & $\mathrm{E}$ & \\
\hline $\mathrm{Hg}$ & 0.03 & $E$ & \\
\hline $\mathrm{K}$ & 631 & $\mathrm{E}$ & \\
\hline $\mathrm{La}$ & 1250 & $\mathrm{E}$ & \\
\hline $\mathrm{Mn}$ & 1250 & $\mathrm{E}$ & \\
\hline $\mathrm{Na}$ & 3530 & $\mathrm{E}$ & . \\
\hline $\mathrm{Ni}$ & 19.1 & E & \\
\hline $\mathrm{NO}_{2}$ & 52 & $\mathrm{E}$ & \\
\hline $\mathrm{NO}_{3}$ & 6,020 & $\mathrm{E}$ & \\
\hline $\mathrm{OH}_{\text {TOTAL }}$ & 3,460 & $\mathrm{C}$ & \\
\hline $\mathrm{P}$ as $\mathrm{PO}_{4}$ & 852 & $\mathrm{E}$ & \\
\hline $\mathrm{Pb}$ & 60 & $\mathrm{E}$ & \\
\hline $\mathrm{S}$ as $\mathrm{SO}_{4}$ & 134 & $\mathrm{E}$ & \\
\hline
\end{tabular}




\section{Revision 0}

Table D4-1. Best-Basis Inventory Estimate for Nouradioactive Components in Tank 241-T-202 (Effective May 31, 1997). (2 Sheets)

\begin{tabular}{|c|c|c|c|}
\hline Analyte & $\begin{array}{c}\text { Total inventory } \\
(\mathrm{kg})\end{array}$ & $\begin{array}{c}\text { Basis } \\
(\mathrm{S}, \mathrm{M}, \mathrm{E}, \text { or } \mathrm{C})^{1}\end{array}$ & Comment \\
\hline $\mathrm{Si}$ & 311 & $\mathrm{E}$ & \\
\hline $\mathrm{Sr}$ & 55 & $\mathrm{E}$ & \\
\hline $\mathrm{TOC}$ & 269 & $\mathrm{E}$ & \\
\hline $\mathrm{U}_{\text {TOTAL }}$ & 20.5 & $\mathrm{E}$ & \\
\hline $\mathrm{Zr}$ & 0.54 & $\mathrm{E}$ & \\
\hline
\end{tabular}

${ }^{1} \mathrm{~S}=$ Sample-based

$\mathrm{M}=$ Hanford Defined Waste model-based, Agnew et al. (1997a)

$\mathrm{E}=$ Engineering assessment-based

$\mathrm{C}=$ Calculated by charge balance; includes oxides as hydroxides, not including $\mathrm{CO}_{3}, \mathrm{NO}_{2}, \mathrm{NO}_{3}, \mathrm{PO}_{4}, \mathrm{SO}_{4}$, and $\mathrm{SiO}_{3}$ 


\section{Revision 0}

Table D4-2. Best-Basis Inventory Estimate for Radioactive Components in Tank 241-T-202, Decayed to January 1, 1994 (Effective May 31, 1997). (2 Sheets)

\begin{tabular}{|c|c|c|c|}
\hline Analyte & $\begin{array}{l}\text { Total Inventory } \\
\text { (Ci) }\end{array}$ & $\begin{array}{c}\text { Basis } \\
(\mathrm{S}, \mathrm{M}, \text { or } \mathrm{E})^{1} \\
\end{array}$ & Comment \\
\hline${ }^{3} \mathrm{H}$ & $4.22 \mathrm{E}-04$ & $\mathrm{M}$ & \\
\hline${ }^{14} \mathrm{C}$ & $1.31 \mathrm{E}-04$ & $\mathrm{M}$ & \\
\hline${ }^{59} \mathrm{Ni}$ & 3.72 E-05 & M & \\
\hline${ }^{60} \mathrm{Co}$ & 4.20 E-05 & $\mathrm{M}$ & $\cdot$ \\
\hline${ }^{63} \mathrm{Ni}$ & 0.00343 & $\mathrm{M}$ & \\
\hline${ }^{79} \mathrm{Se}$ & 2.76 E-05 & $\mathrm{M}$ & \\
\hline${ }^{90} \mathrm{Sr}$ & 349 & $\mathrm{E}$ & \\
\hline${ }^{90} \mathrm{Y}$ & 349 & $\mathrm{E}$ & Based on ${ }^{90} \mathrm{Sr}$ value \\
\hline${ }^{93 \mathrm{~m}} \mathrm{Nb}$ & $1.08 \mathrm{E}-04$ & M & \\
\hline${ }^{93} \mathrm{Zr}$ & $1.31 \mathrm{E}-04$ & M & \\
\hline${ }^{99} \mathrm{Tc}$ & 9.09 E-04 & M & \\
\hline${ }^{106} \mathrm{Ru}$ & $3.15 \mathrm{E}-11$ & M & \\
\hline${ }^{113 \mathrm{~m}} \mathrm{Cd}$ & 3.67. E-04 & M & \\
\hline${ }^{125} \mathrm{Sb}$ & $4.84 \mathrm{E}-05$ & $\mathrm{M}$ & \\
\hline${ }^{126} \mathrm{Sn}$ & $4.16 \mathrm{E}-05$ & M & \\
\hline${ }^{129} \mathrm{I}$ & $1.72 \mathrm{E}-06$ & $\mathrm{M}$ & \\
\hline${ }^{134} \mathrm{Cs}$ & $2.09 \mathrm{E}-06$ & $\mathrm{M}$ & \\
\hline${ }^{137 \mathrm{~m}} \mathrm{Ba}$ & 2.3 & $\mathrm{E}$ & Based on ${ }^{137} \mathrm{Cs}$ \\
\hline${ }^{137} \mathrm{Cs}$ & 2.4 & $\mathrm{E}$ & \\
\hline${ }^{151} \mathrm{Sm}$ & 0.104 & $\mathrm{M}$ & \\
\hline${ }^{152} \mathrm{Eu}$ & 1.37 E-04 & $\mathrm{M}$ & \\
\hline${ }^{154} \mathrm{Eu}$ & $6.74 \mathrm{E}-04$ & $\mathrm{M}$ & \\
\hline${ }^{155} \mathrm{Eu}$ & 0.0123 & $\mathrm{M}$ & \\
\hline${ }^{226} \mathrm{Ra}$ & $6.16 \mathrm{E}-09$ & $\mathrm{M}$ & \\
\hline${ }^{227} \mathrm{Ac}$ & $3.25 \mathrm{E}-08$ & M & \\
\hline${ }^{228} \mathrm{Ra}$ & $3.96 \mathrm{E}-13$ & M & \\
\hline${ }^{229} \mathrm{Th}$ & 7.67 E-11 & M & \\
\hline${ }^{231} \mathrm{~Pa}$ & $7.51 \mathrm{E}-08$ & $\mathrm{M}$ & \\
\hline
\end{tabular}


Table D4-2. Best-Basis Inventory Estimate for Radioactive Components in Tank 241-T-202, Decayed to January 1, 1994 (Effective May 31, 1997), (2 Sheets)

\begin{tabular}{|c|c|c|c|}
\hline Analyte & $\begin{array}{c}\text { Total Inventory } \\
(\mathrm{Ci})\end{array}$ & $\begin{array}{c}\text { Basis } \\
(\mathrm{S}, \mathrm{M}, \text { or } \mathrm{E})^{1}\end{array}$ & Comment \\
\hline${ }^{232} \mathrm{Th}$ & $3.46 \mathrm{E}-14$ & $\mathrm{M}$ & \\
\hline${ }^{232} \mathrm{U}$ & $4.02 \mathrm{E}-08$ & $\mathrm{M}$ & \\
\hline${ }^{233} \mathrm{U}$ & $1.83 \mathrm{E}-09$ & $\mathrm{M}$ & \\
\hline${ }^{234} \mathrm{U}$ & 0.002 & $\mathrm{M}$ & \\
\hline${ }^{235} \mathrm{U}$ & $8.92 \mathrm{E}-05$ & $\mathrm{M}$ & \\
\hline${ }^{236} \mathrm{U}$ & $1.75 \mathrm{E}-05$ & $\mathrm{M}$ & \\
\hline${ }^{237} \mathrm{~Np}$ & $5.63 \mathrm{E}-06$ & $\mathrm{M}$ & \\
\hline${ }^{238} \mathrm{Pu}$ & $2.40 \mathrm{E}-04$ & $\mathrm{M}$ & \\
\hline${ }^{238} \mathrm{U}$ & 0.00203 & $\mathrm{M}$ & \\
\hline${ }^{239240} \mathrm{Pu}$ & 19 & $\mathrm{E}$ & \\
\hline${ }^{239} \mathrm{Pu}$ & 0.0348 & $\mathrm{M}$ & \\
\hline${ }^{240} \mathrm{Pu}$ & 0.00306 & $\mathrm{M}$ & \\
\hline${ }^{241} \mathrm{Am}$ & 6.14 & $\mathrm{E}$ & \\
\hline${ }^{241} \mathrm{Pu}$ & 0.0101 & $\mathrm{M}$ & \\
\hline${ }^{242} \mathrm{Cm}$ & $2.78 \mathrm{E}-06$ & $\mathrm{M}$ & \\
\hline${ }^{242} \mathrm{Pu}$ & $4.67 \mathrm{E}-08$ & $\mathrm{M}$ & \\
\hline${ }^{243} \mathrm{Am}$ & $2.31 \mathrm{E}-09$ & $\mathrm{M}$ & \\
\hline${ }^{243} \mathrm{Cm}$ & $5.99 \mathrm{E}-08$ & $\mathrm{M}$ & \\
\hline${ }^{244} \mathrm{Cm}$ & $5.88 \mathrm{E}-08$ & $\mathrm{M}$ & \\
\hline${ }^{\mathrm{S}} \mathrm{S}$ & & \\
\hline
\end{tabular}

${ }^{1} \mathrm{~S}=$ Sample-based

$\mathrm{M}=$ Hanford Defined Waste model-based, Agnew et al. (1997a)

$\mathrm{E}=$ Engineering assessment-based 
HNF-SD-WM-ER-727

Revision 0

This page intentionally left blank.

D-16 
HNF-SD-WM-ER-727

Revision 0

\section{D5.0 APPENDIX D REFERENCES}

Agnew, S. F., J. Boyer, R. A. Corbin, T. B. Duran, J. R. FitzPatrick, K. A. Jurgensen, T. P. Ortiz, and B. L. Young, 1997a, Hanford Tank Chemical and Radionuclide Inventories: HDW Model Rev. 4, LA-UR-96-3860, Los Alamos National Laboratory, Los Alamos, New Mexico.

Agnew, S. F., R. A. Corbin, T. B. Duran, K. A. Jurgensen, T. P. Ortiz, and B. L. Young, 1997b, Waste Status and Transaction Record Summary (WSTRS Rev. 4), LA-UR-97-311, Rev. 0, Los Alamos National Laboratory, Los Alamos, New Mexico.

Anderson, J. D., 1990, A History of the 200 Area Farms, WHC-MR-0132, Westinghouse Hanford Company, Richland, Washington.

Borsheim, G. L., 1994, Bismuth Phosphate 224 Building Waste Data, Memo to Distribution Westinghouse Hanford Company, Richland Washington.

Field, J.G., K. M. Hodgson, and R. T. Winward (Meier Associates), 1997, Tank Characterization Report for Single-Shell Tank 241-B-202, HNF-SD-WM-ER-371, Rev. OA, Lockheed Martin Hanford Corporation, Richland, Washington.

Hanlon, B. M., 1997, Waste Tank Summary Report for Month Ending March 31, 1997, WHC-EP-0182-108, Lockheed Martin Hanford Corporation, Richland, Washington.

Hill, J. G., G. S. Anderson, and B. C. Simpson, 1995, The Sort on Radioactive waste Type Model: A Method to Sort Single-Shell Tanks into Characteristic Groups, PNL-9814, Rev. 2, Pacific Northwest Laboratory, Richland, Washington.

Hodgson, K. M., and M. D. LeClair, 1996, Work Plan for Defining a Standard Inventory Estimate for Wastes Stored in Hanford Site Underground Tanks, WHC-SD-WM-WP-311, Rev. 1, Lockheed Martin Hanford Corporation, Richland, Washington.

Kupfer, M. J., A. L. Boldt, B. A. Higley, K. M. Hodgson, L. W. Shelton, and R. A. Watrous (LMHC), S. L. Lambert, and D. E. Place (SESC), R. M. Orme (NHC), G. L. Borsheim (Borsheim Associates), N. G. Colton (PNNL), M. D. LeClair (SAIC), R. T. Winward (Meier Associates), and W. W. Schulz (W²S Corporation), 1997, Standard Inventories of Chemicals and Radionuclides in Hanford Site Tank Wastes, HNF-SD-WM-TI-740, Rev. 0, Lockheed Martin Hanford Corporation, Richland, Washington.

Pool, K. N., 1994, Single-Shell Tank Characterization Tank B-202 Cores 24 and 25, WHC-SD-WM-DP-034, Rev. 0, Westinghouse Hanford Company, Richland, Washington. 


\section{HNF-SD-WM-ER-727}

\section{Revision 0}

Watrous, R. A., and D. W. Wootan, 1997, Activity of Fuel Batches Processed Through Hanford Separations Plants, 1944 Through 1989, HNF-SD-WM-TI-794, Rev. 0, Lockheed Martin Hanford Corporation, Richland, Washington. 